\title{
Green Gentrification and Environmental Injustice: A Discussion Based on the New Pinheiros River Program, São Paulo, Brazil
}

\author{
Estela Macedo Alves ${ }^{1 *}$, Mariana Gutierres Arteiro da Paz ${ }^{2}$ and Ana Paula Fracalanza ${ }^{3}$ \\ ${ }^{1}$ Energy and Environment Institute, Universidade de São Paulo, São Paulo, Brazil, ${ }^{2}$ National Institute for Space Research, \\ São José dos Campos and Energy and Environment Institute, Universidade de São Paulo, São Paulo, Brazil, ${ }^{3}$ School of Arts, \\ Sciences, and Humanities, Universidade de São Paulo, São Paulo, Brazil
}

\section{OPEN ACCESS}

Edited by:

Pedro Roberto Jacobi,

University of São Paulo, Brazil

Reviewed by:

Luis Fernando Novoa Garzon,

Federal University of Rondonia, Brazil

Victor Kinjo

University of Sao Paulo, Brazil

${ }^{*}$ Correspondence:

Estela Macedo Alves

alvesestela@usp.br

Specialty section:

This article was submitted to

Urban Greening,

a section of the journal

Frontiers in Sustainable Cities

Received: 21 March 2021

Accepted: 12 October 2021

Published: 25 November 2021

Citation:

Alves EM, Paz MGAd and

Fracalanza AP (2021) Green

Gentrification and Environmental Injustice: A Discussion Based on the New Pinheiros River Program, São

Paulo, Brazil.

Front. Sustain. Cities 3:683660.

doi: $10.3389 /$ frsc. 2021.683660
Through the analysis of the New Pinheiros River Program, São Paulo, Brazil, the differences in the solutions presented are considered to implement environmental projects in different territories over the same sub-basin. Vulnerable neighborhoods upstream will receive only basic infrastructure; while Marginal Pinheiros, a rich place, will be contemplated with aditional leisure, sports and cultural equipments. The general aim is to analyze the process of capitalist production of the Pinheiros River depolluting program area, proposed by the São Paulo State government in 2019, as well as green gentrification and creation of environmental injustice. Methodology consists of bibliographic research and analysis of the program's documents and speeches of people in charge. Global South cities have been experimenting environmental injustice as a result of financial capital investments.

Keywords: green gentrification, New Pinheiros River Program, Global South, environmental justice, sanitation

\section{INTRODUCTION}

Paragraph: In the last decades, the search for urban environmental sustainability has been followed by environment improvement and development projects. However, when lacking rogatory policies considering urban functions and the social characteristics of neighboring populations, they may lead to social exclusion, characterizing a process of green gentrification (Gould and Lewis, 2017; Anguelovski I. et al., 2018; Immergluck and Balan, 2018; Blok, 2020; Yazar et al., 2020) and social injustice for depriving populations of these improvements (Gould and Lewis, 2017).

This paper discusses the expansion of the phenomenon of gentrification in the region known as Marginal do Rio Pinheiros, in São Paulo, that has been occurring since the 1970s. The region used to be an industrial and middle-class neighborhood that has been transformed into a predominant business center of high technology buildings, constructed after public investments in urban requalification and transport systems (Nobre, 2000). In the 1990s, new public investments turned the region into a showcase of globalization, based on public-private partnership and real estate production through financial capital (Fix, 2007).

This study case is the New Pinheiros River Program (NPRP) started by São Paulo State Government, in 2019, as a stage of the 4th phase of the Tietê River Depollution Program (TRDP), 
the largest environmental sanitation program in Brazil, that has been in progress, since the 1990 (SABESP, 2018, 2019a,b).

The article aims to analyze the capitalist production of urban space and its relation to the intensification of gentrification at Pinheiros River side through green projects in contrast to the permanence of environmental injustice in poor neighborhoods, inside the territory of Rio Pinheiros sub-basin.

Through the observation of this on-going case, we ask whether it is possible to create cities with better environmental quality for all or the program will enhance socio-environmental inequality, since there are populations in poverty and environmental risk situations in the area, that will be disproportionately benefited. There will be intensification of the valorization of urban space at Marginal do Rio Pinheiros, through public-private partnership, while the program limits its actions to implement drainage and basic sewage systems in the poorest neighborhoods of the same river basin territory (SABESP, 2019a).

Discussions contextualize the studied case with experiences of the Global South, which can be understood as a view over development emphasizing geopolitical power relation patterns and the prevalence of poverty all throughout Latin American, Asian, African, and Oceanian countries (Dados and Connell, 2012; Watson, 2019; Gosens, 2020), characterizing places and populations negatively affected by contemporary globalization (Mahler, 2017). The Metropolitan Region of São Paulo (MRSP) is composed of irregular urban territories, including illegal ones, in both urbanistic and environmental terms and lacking infrastructure, which shelter socio-environmentally vulnerable populations. However, it is known that the necessary investments to correct environment risks and frailty issues bring forth property valorization and may contribute to cast out the same population in need for benefits.

\section{STUDIED AREA}

The Pinheiros River Basin territory is in the MRSP, State of São Paulo, Brazil. It is the country's most populated area, with $\sim 21$ million inhabitants (EMPLASA., 2016). This river basin is composed of 25 other sub-basins (SABESP, 2019a). The hydrographic region is located among 12 of the 39 MRSP municipalities (Figure 1) (SABESP, 2019b).

The specific NPRP covers $271 \mathrm{~km}^{2}$ and includes neighborhoods in São Paulo, Embu das Artes, and Taboão da Serra [São Paulo (State), 2019a]. The other municipalities will be indirectly benefited, according to a document provided by the São Paulo Basic Sanitation Company (SABESP).

Part of the territory impacted by the NPRP has already undergone several urban interventions, specially at the Marginal Pinheiros region. In 1927, the Billings Reservoir, by the Light Electric Power Company, was built to generate hydroelectric energy at the Henry Borden Plant, with severe changes in the Pinheiros River body (Luz and Rodrigues, 2020). As a mechanism for generating additional electricity at the plant and to control floods, it was made a system of pumping of the waters of the Pinheiros River, and its flow was reversed.
The mechanism brought additional pollutants from the Tietê River, contaminated by industrial effluents and domestic sewage (Luz and Rodrigues, 2020).

Therefore, there are different socioeconomic territories inside the sub-basin of Rio Pinheiros, target of the NPRP, and different public actions were planned for each territory [São Paulo (State), 2021b]. Marginal Pinheiros, already high valued and with a big offer of urban equipment, will receive sewage and drainage systems, and investments in innovative equipment of leisure, sports, and culture, close to the Cidade Jardim bridge [São Paulo (State), 2021b], one of the richest regions of São Paulo city.

Territories of low-income communities, slums, and middleclass neighborhoods will just receive the basic, namely, sewage and drainage systems and proper solid waste management, although they are socially vulnerable territories with deficit of public equipment of leisure, sports, and culture.

\section{SOCIO-ENVIRONMENTAL VULNERABILITY IN THE CAPITALIST PRODUCTION OF URBAN SPACE}

According to neo-Marxist urban sociology theories, the formation of cities in capitalism is interpreted under the perspective of decisions on land investments, escalating unequal relations between the working and capitalist classes, which include the access to collective consumption goods, as the green infrastructure (Alves and Fracalanza, 2019).

The formation of cities was important to the development of capitalism, in which lands were transformed into commodities and became financial assets, and infrastructure was essential for capital and workforce circulation (Harvey, 1992). Durable high cost of production goods enabled by urban infrastructure do not generate profit, despite adding high value to places they are implemented in (Marques, 2003). Man-made landscapes in capitalist cities follow the logic of accumulation and class conflict, creating unequal territories, with differences in investment quality and quantity (Alves and Fracalanza, 2019).

Contemporary urban planning is characterized by zoning laws and master plans that meet real estate and other private groups' interests, overlooking the collective needs. Urban space production is no longer based on mechanisms for territory planning but the result of market influence (Harvey, 2002).

Urban land is used within economic planning as a commodity over a part of city planning, as a social space for sociability and for the satisfaction of inhabitant needs, including the need for environmental quality (Alves and Fracalanza, 2019). Brazilian cities remain socially unequal and unfair, answering to real estate capital and political interests through investments on great construction works. Basic infrastructure and the improvement of inhabiting conditions for most of the population are disregarded (Maricato, 2013).

The city of São Paulo suffers with contrast between investments in noble areas and the lack of infrastructure in peripheral ones, especially due to slavery heritage, maintained through a patrimonial legal order consolidated by conservative modernization projects (Ferreira, 2011). 


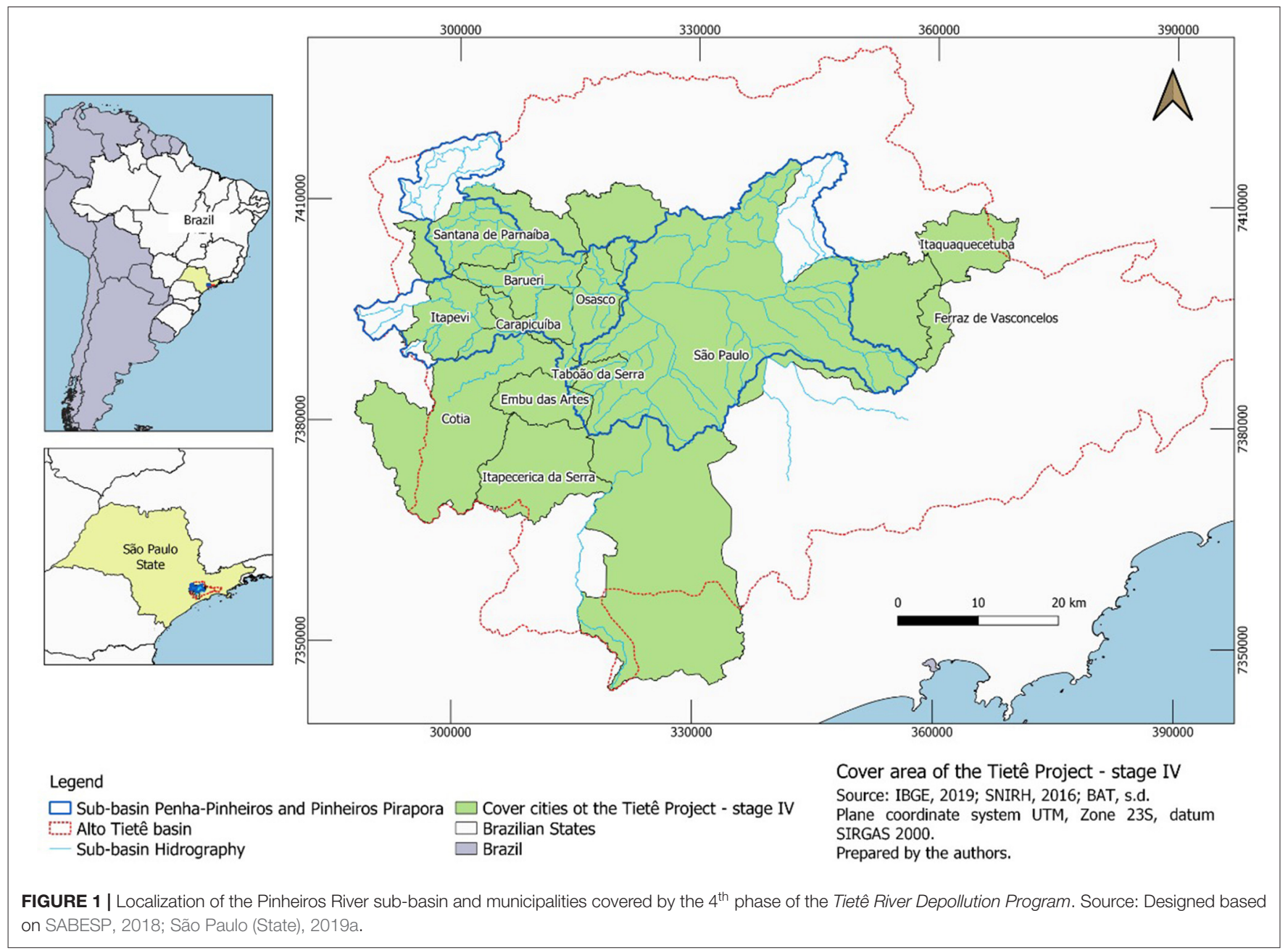

\section{GREEN GENTRIFICATION-CAN GREEN INTERVENTIONS BE SUBVERSIVE?}

Studies on green gentrification have been identifying and questioning the processes of environmental improvements in a capitalist scenario, which result in real state valuation around the interventions, and produce the expulsion of the poorest social classes of the area (Curran and Hamilton, 2012; Gould and Lewis, 2012; Pearsall, 2012); in this case, vulnerable populations will remain far from part of the environmental improvements by public actions applied in urban equipment at Marginal Pinheiros. When implemented, green gentrification processes also characterize environmental injustice (Curran and Hamilton, 2012).

Recent publications on green gentrification commonly identify relations between populations excluded from these improvements and social class, race, and other social factors that characterize exclusion (Gould and Lewis, 2017; Anguelovski O. et al., 2018; Immergluck and Balan, 2018; Blok, 2020; Goossens et al., 2020; Yazar et al., 2020). In this sense, we ask whether these projects could be called environmental improvements while excluding populations by social class and/or race. After all, what is "environment" or what do we refer to when using the term "environmental"?

The understanding of environmental sustainability has been increasingly integrating the "total environment concept" (Smith et al., 1999). Environmental complexity demands integration of many study fields to fully consider it, and a view "that considers the natural, built, and social environments together with a persons inherent or intrinsic biological determinants, activities/behaviors, and policies/programs over different life stages and generations" (EPA).

The Global Environmental Agenda itself has evolved since the Agenda 21 in 1992 to the Sustainable Development Goals (SDG) in 2018, which included social matters, such as gender, race, and poverty, among other necessary paths for countries to follow in search of sustainability (United Nations, 2021). Therefore, we ask: was there actual environmental improvement, even with losses for the society affected by the intervention?

\section{ENVIRONMENTAL JUSTICE}

Green gentrification can increase inequality and environmental injustice, depending on how it deals with different inhabitants 
and populations. Environmental injustice is the process in which socio-economically unequal societies allocate most environmental damages to low-income populations, discriminated racial groups, socio-economically vulnerable populations, and discriminated minorities (Acselrad et al., 2009).

Environmental injustice is related to the term "Environmental Racism," a form of institutionalized discrimination (Bullard, 2004, p. 43). Bullard's research in 1987 showed that the localization of hazardous waste warehouses in the USA was strongly connected to racial and class factors, while race was, in that case, a stronger indicator of the correspondence between the place people live and toxic waste warehouses (Bullard, 2004, p. 20), with prevalence for Afro-American, Latinos, and Native Americans (Martinez Alier, 2009).

Unequal exposure to environmental risks due to development processes for socio-environmentally vulnerable populations and minorities is environmental injustice, as well as unequal access to environmental resources (Acselrad et al., 2009). In this work, unequal access to land or expulsion from privileged urban areas are considered cases of environmental injustice.

\section{NEW PINHEIROS RIVER PROGRAM}

This study case is the NPRP started by the São Paulo State Government, in 2019, as a stage of the 4th phase of the TRDP. The NPRP aims to return a clean Pinheiros River for the population until 2022 [SABESP, 2019a; São Paulo (State), 2021b]. It involves several state bodies responsible for sanitation services.

Besides infrastructure implementation, the NPRP establishes the recovery of the margins of Rio Pinheiros, around the area known as Marginal Pinheiros, with the construction of leisure equipment and a linear park, that were granted to private initiative for exploitation [São Paulo (State), 2021b]. One of them will be implemented at a former water lifting plant (UE Traição), based on the model of the Argentinian neighborhood Puerto Madero, in Buenos Aires [São Paulo (State), 2019a].

The program counts with financial resources from funding contracts with the Inter-American Development Bank (IDB) and the World Bank Group (WBG) of US\$ 405.2 million (R\$ 2.197 billion), besides US\$ 105.8 million (R\$ 1.198 billion) as SABESP's compensation [São Paulo (State), 2019b]. All amounts in reais in this article were updated to reais in February 2021 and converted into dollars in February 2021.

Regarding the participation of the population, SABESP indicates that popular engagement is important for the project's success, in the form of effective connection to sewage systems and the proper disposal of waste, so that it does not end in the rivers. The company also mentions that populations in informal areas will receive improvements, and that big companies and other segments will also be benefited [SABESP, 2019c; São Paulo (State), 2021b]. Engagement mechanisms for civil society were Community Consultation, Community Communication (SABESP, 2018), and Public Hearings (SABESP, 2019c).

SABESP carried out three public hearings with IDB for the communities covered by the 4 th phase of the TRDP. The hearings happened in all three regions, at accessible days and times for workers (weekends and at night on weekdays) (SABESP, $2019 b)$. The forms of social participation declared in the project's communication and advertising means were characterized by consultive and informative processes, with passive features and little or no possible action and/or decision-making by the population (Paz and Fracalanza, 2020).

The schedule fits the duration of the current governor office (2018-2022), focused on works on regions of high real estate value in the municipality of São Paulo. These aspects indicate economic objectives in the state plan, focused on widening businesses and development for the MRSP.

The NPRP is clearly a project of sustainability used to value territories already important for real estate market and financial investors. Technically, depollution of the Pinheiros River requires actions for cleaning the contribution drainage area upstream, where are localized the residential area benefited with systems of sewage, drainage, and garbage collection. There are $\sim 400,000$ families that already received this basic infrastructure, since 2019 [São Paulo (State), 2021b].

The important factor to be considered for the poorest territories covered by the NPRP is that part of the households is judicially irregular, so they cannot receive infrastructure of any kind, mainly because they affront the law for the protection of water sources (Lei Estadual no. 9.866/1997). In those cases, the houses in social and environmental vulnerable situation will not be benefited by the NPRP: there will just be constructed small treatment plants, the Water Quality Recovery Unities, and the water will be treated directly on water streams, before it flows into the Pinheiros River [São Paulo (State), 2021b].

This is a palliative solution, which links the two territories covered by NPRP, highlighting the situation of environmental injustice, where the most vulnerable population will continue living with pollution from sewage, while the richest territories comprised in NPRP will have access to treated downstream water, leisure, sports, culture, and consumptions equipment, at the Marginal Pinheiros neighborhood.

The discussion proposed here over this project is whether this investment around a water stream, a common good, that will serve to further appreciate noble neighborhoods in the city is really a government program aiming to promote environmental quality fairly and democratically.

Public information made available by SABESP affirms that 16 contracts to expand and improve sewage collection and transportation to an existing treatment facility are in execution (SABESP, 2019a). Still, investments in parks and sports, leisure, and service structure are focused only on the noble part of the city and not on the areas to receive sewage connection.

Regarding the program's business potential, after the Pinheiros River depollution, government representatives inform that there will be economic exploitation of the river in activities as: navigation, sports, bike path, and "creative economy," gastronomy, and other services [São Paulo (State), 2019a]. The depollution program actions involve the private sector and the sanitation company SABESP, each in one project phase to reach the program's aim: to clean the river; provide urbanism and 
touristic exploration; grant train lines in the region to private companies; build new accesses through pedestrian walkways; and actions for nighttime use in the region. The final aim is to appreciate the surrounding areas using the least public resources possible [São Paulo (State), 2019a].

More investments were recently proposed for the program through a partnership between the São Paulo State government and private initiative for the linear park at the Pinheiros River margins. The park is located in a region of high real estate value and restricted access to most of the population, especially due to the neighborhood gentrification, which refrains the access of people from other areas, characterizing an improvement focused on a part of the population, corroborating Gould and Lewis (2017) studies on green gentrification in Brooklyn, New York.

Regarding the creation of the São Paulo Puerto Madero, in November 2020, the state government signed a contract to revitalize the former Traição Plant with the Metropolitan Water and Energy Company S.A. (EMAE) and the São Paulo Plant Venture SPE S.A. [São Paulo (State), 2020a]. The concession price was US\$ 56.6 million (R \$ 307 million) in February 2021 and was signed after financial and environmental debate, in February and April of that year, by a state government body responsible to establish free competition [São Paulo (State), 2020a,b].

The environmental debate considered that there are Permanent Conservation Areas (APPs) among the granted areas, with restriction for the construction of new buildings, as well as the lack of technical reports on structural conditions of the Traição Plant building, constructed more than 80 years ago with no projection of "use intensification" [São Paulo (State), 2020b].

Concerning the linear park, its contract was signed in January 2021 between the Metropolitan Water and Energy Company S.A. (EMAE) and the New Pinheiros River Park Venture. The contract establishes a US\$ 5.8 million ( $\mathrm{R} \$ 31.5$ million) investment in the next 5 years for the implantation and maintenance of park infrastructure [São Paulo (State), 2021c]. Although park equipment is free, there are compensations for private investment allowing advertising and event organization in the granted area, which can lead to environmental injustice [São Paulo (State), 2019a]. Therefore, the population that contributes the least to environmental problems could be excluded from private events foreseen in the park grant, clearly leading to the requalification of public areas for private initiative and to a case of environmental injustice (Acselrad et al., 2009).

\section{FINAL REMARKS: REQUALIFICATION AND GREEN GENTRIFICATION}

This article aimed to discuss the NPRP proposed by the São Paulo state government that connects river depollution to two works considered as the main results of the program: a leisure area and the construction of a linear park.

According to the analysis, the leisure area, called São Paulo Puerto Madero, is a construction model based on excluding capitalist consumption, despite the area reconstruction depending on basic sanitation works performed by the São Paulo State government.

As for green gentrification, it is considered that there is a possibility that the process will be observed in the next years after the implementation of the sustainable green structures as the linear park, leisure, and sports equipment at Marginal Pinheiros. According to the São Paulo government, the depollution of the River Pinheiros will result in real state valuation of neighborhoods in the immediate surroundings of Marginal Pinheiros [São Paulo (State), 2021a]. Associated with the implantation of the Puerto Madero Paulistano, the raise of value of the neighborhoods could lead to the expulsion of lower- and middle-income populations from these places, which would result in continuous green gentrification processes.

This mode of production of qualified and valued urban spaces included in the ranking of global cities is supported by public resources invested in infrastructure, with the purpose of leveraging private business (Fix, 2007). As controversial results, these public investments generate more socio-spatial segregation, deepen processes of environmental injustice, and may in the future result in green gentrification depending on capital investments.

Lastly, it is important to observe that cities in the Global South have been the focus of exploration by the international financial capital, which expands to occupy new markets, such as water and sanitation. The NPRP thus fits this expansion logic of the financial capital that invests on Global South cities aiming to widen markets and profits, but not to improve environmental quality or proposing solutions for the promotion of environmental justice. In this case, green gentrification is one path for such international investment.

As alternatives for processes of green gentrification, as this case, the construction of linear parks in public areas located in low-income neighborhoods should be considered, contributing to environmental justice. And more ambitious could be the partnership with the cities involved in the project to improve informal communities and favelas, with urbanization investments or production of social housing, this way looking toward a real environmental sustainability, instead of the constructions of exclusionary leisure structures. Urban sustainability connected to social housing is a strategy that has been proposed by UN Habitat, to achieve sustainable development (Ministério do Meio Ambiente et al., 2015), The criticism presented here is about the precarious housing situation of part of the families covered by the NPRP and the communities living without access to urban equipment, basic sanitation, and proper garbage collection; however, the investments in sustainability and urban requalification were primarily designed downstream, at the Marginal Pinheiros neighborhood, where high technological commercial buildings impose characteristics of global city. The project covers only one sub-basin territory but proposes two unequal solutions. So, we observe that the NPRP is a continuity of the perverse logic of 
capitalist urban space production that widens inequalities in the territory.

\section{AUTHOR CONTRIBUTIONS}

All authors listed have made a substantial, direct, and intellectual contribution to the work and approved it for publication.

\section{REFERENCES}

Acselrad, H., Mello, C. C. A., and Bezerra, G. N. (2009). O que é Justiça Ambiental. Rio de Janeiro: Garamond.

Alves, E. M., and Fracalanza, A. P. (2019). O lugar do saneamento nas cidades do capitalismo. Anais IX Encontro Nacional da ANPPAS.

Anguelovski, I., Connolly, J. J. T., Masip, L., and Pearsall, H. (2018). Assessing green gentrification in historically disenfranchised neighborhoods: a longitudinal and spatial analysis of Barcelona. Urban Geogr. 39, 458-491. doi: 10.1080/02723638.2017.1349987

Anguelovski, O., Connolly, J., and Brand, A. L. (2018). From landscapes of utopia to the margins of the green urban life, City 22, 417-436. doi: $10.1080 / 13604813.2018 .1473126$

Blok, A. (2020). Urban green gentrification in an unequal world of climate change. Urban Stud. 57, 2803-2816. doi: 10.1177/0042098019891050

Bullard, R. (2004). "Enfrentando o racismo ambiental no século XXI," in Justiça Ambiental e Cidadania, (Rio de Janeiro: Relume Dumará; Fundação Ford), 41-68.

Curran, W., and Hamilton, T. (2012). Just green enough: contesting environmental gentrification in Greenpoint, Brooklyn. Local Environ. 17, 1027-1042. doi: 10.1080/13549839.2012.729569

Dados, N., and Connell, R. (2012). The global south. Contexts 11, 12-13. doi: $10.1177 / 1536504212436479$

EMPLASA. (2016). Empresa Paulista de Planejamento Metropolitano Plano de Desenvolvimento Urbano Integrado (PDUI). Available online at: https://www. pdui.sp.gov.br/rmsp/?page_id=56\#: :text=Os\%20n\%C3\%BAmeros\%20da \%20RMSP\%20impressionam,novos\%20habitantes\%20a\%20cada\%20hora (accessed February 9, 2021).

EPA. (No date). United States Environmental Protection Agency. Available online at: https://www.epa.gov/research-grants/using-total-environment-frameworkbuilt-natural-social-environments-assess-life-long (accessed February 2021).

Ferreira, J. S. W. (2011). São Paulo: cidade da intolerância, ou o urbanismo "à Brasileira". Revista Estudos Avançados 25, 73-88. doi: 10.1590/S0103-40142011000100006

Fix, M. (2007). São Paulo, Cidade global: fundamentos financeiros de uma miragem. São Paulo: Boitempo, 192.

Goossens, C., Oosterlynck, S., and Bradt, L. (2020). Livable streets? green gentrification and the displacement of longtime residents in Ghent. Urban Geograph. 41, 550-572. doi: 10.1080/02723638.2019.1686307

Gosens, J. (2020). The greening of South-South trade: levels, growth, and specialization of trade in clean energy technologies between countries in the global South. Renewable Energy. 6:14. doi: 10.1016/j.renene.2020.06.014

Gould, K., and Lewis, T. (2012). "The environmental injustice of green gentrification: the case of brooklyn's prospect park," in The World in Brooklyn: Gentrification, Immigration, and Ethnic Politics in a Global City, eds J. DeSena and T. Shortell (Lanham, MD: Lexington Books), 113-146.

Gould, K. A., and Lewis, T. L. (2017). Green gentrification. Urban Sustainability and the Struggle for Environmental Justice. London: Routledge.

Harvey, D. (1992). The Urban Experience. Oxford: Blackwell Publishers.

Harvey, D. (2002). Condição pós-moderna. São Paulo: Editora Loyola.

Immergluck, D., and Balan, T. (2018). Sustainable for whom? green urban development, environmental gentrification, and the Atlanta Beltline. Urban Geograph. 39, 546-562. doi: 10.1080/02723638.2017.1360041

Luz, R. A., and Rodrigues, C. (2020). O processo histórico de ocupação e de ocorrência de enchentes na planície fluvial do rio Pinheiros

\section{FUNDING}

This work was funded by Instituto de Energia e Ambiente Universidade de São Paulo - PROEX found and Coordenação de Aperfeiçoamento de Pessoal de Nível Superior (CAPES) - Process: Programa Nacional de Pós-Doutorado / Processo 88887.337883/2019-00.

de 1930 até os dias atuais. Geousp-Espaço e Tempo (On-line), v. 24, 340-360.doi: 10.11606/issn.2179-0892.geousp.2020.164499

Mahler, A. G. (2017). Global south-literary and critical theory. Oxford Bibliograph. 25:55. doi: 10.1093/obo/9780190221911-0055

Maricato, E. (2013). "Cidades e luta de classes no Brasil," in Fundação Perseu Abramo e Fundação Friedrich Ebert (org). Classes? Que Classes? Ciclo de debates sobre classes sociais. São Paulo: Editora Fundação Perseu Abramo, 138-161.

Marques, E. C. (2003). Redes sociais, instituições e atores políticos no governo da Cidade de São Paulo. São Paulo: Annablume e Fapesp.

Martinez Alier, J. (2009). O ecologismo dos pobres: conflitos ambientais e linguagens de valoração. São Paulo: Contexto.

Ministério do Meio Ambiente., Ministério das Cidades., and ONU Habitat (2015). Sustentabilidade urbana: impactos do desenvolvimento econômico e suas conseqüências sobre o processo de urbanização em países emergentes: textos para as discussões da Rio+20: volume 3 habitação social e sustentabilidade. Available online at: https://antigo.mdr.gov.br/images/stories/ArquivosSNH/ ArquivosPDF/Publicacoes/capacitacao/publicacoes/habitacao_social.pdf

Nobre, E. A. C. (2000). Reestruturação econômica e território: expansão recente do terciário na Marginal do Rio Pinheiros. (Thesis). São Paulo: FAU USP.

Paz, M. G. A., and Fracalanza, A. P. (2020). Social control in basic sanitation at Guarulhos (SP): the Municipal Council of Urban Policies. Ambient. Soc. 23:e00191. doi: 10.1590/1809-4422asoc20190019r1vu2020 $14 \mathrm{ao}$

Pearsall, H. (2012). Moving out or moving in? Resilience to environmental gentrification in New York City. Local Environ. 17, 1013-1026. doi: 10.1080/13549839.2012.714762

SABESP (2018). Avaliação ambiental e social (AAS) e marco de gestão ambiental e social (MGAS) do Programa de despoluição do Rio Tietê - Etapa IV (Tietê IV). São Paulo: SABESP. Available online at: http://site.sabesp.com.br/ site/uploads/file/projeto_tiete/projeto_tiete_versaofinal.pdf (accessed January 31, 2021).

SABESP (2019a). São Paulo Basic Sanitation Company. Projeto Tietê. Available online at: http://site.sabesp.com.br/site/interna/Default.aspx?secaoId=115 (accessed February 6, 2021).

SABESP (2019b). São Paulo Basic Sanitation Company. Novo Rio Pinheiros. Available online at: http://site.sabesp.com.br/site/interna/Default.aspx? secaoId=751 (accessed January 20,2021).

SABESP (2019c). Companhia de Saneamento do Estado de São Paulo. Novo Rio Pinheiros. Disponível em: Available online at: http://site.sabesp.com.br/site/ imprensa/noticias-detalhe aspx ?secaoId=65andid=7841 (accessed January 26, 2021).

São Paulo (State) (2021a). Governo do Estado Revitalização. Available online at: https://novoriopinheiros.sp.gov.br/

São Paulo (State) (2019a). Governo do Estado. Coletiva de Imprensa: Lançamento do Stopover da Latam e Contratos do Novo Rio Pinheiros (accessed October 2, 2021).

São Paulo (State) (2021b). Governo do Estado. Rio Pinheiros ganhará novo parque linear com equipamentos de esporte e lazer. Available online at: https://www.saopaulo.sp.gov.br/spnoticias/rio-pinheiros-ganhara-novoparque-linear-com-equipamentos-de-esporte-e-lazer-2/ (accessed January 29, 2021).

São Paulo (State) (2019b). Secretaria de Infraestrutura e Meio Ambiente - SIMA. Governo de SP e SABESP anunciam R \$ 2,5 bilhões para obras nos rios Pinheiros $e$ Tietê. Available online at: https://www.infraestruturameioambiente.sp.gov.br/ 
2019/12/governo-de-sp-e-sabesp-anunciam-r-25-bilhoes-para-obras-nosrios-pinheiros-e-tiete/ (accessed January 24, 2021).

São Paulo (State) (2020a). Secretaria de Infraestrutura e Meio Ambiente-SIMA. Com ágio de $1.900 \%$, concessão da Usina SP recebe proposta de R\$ $280 \mathrm{mi}$. Available online at: https://www.infraestruturameioambiente.sp.gov.br/2020/ 09/com-agio-de-1-900-concessao-da-usina-sp-recebe-proposta-de-r-280mi/ (accessed February 10, 2021).

São Paulo (State) (2021c). Secretaria de Infraestrutura e Meio Ambiente-SIMA. Novo Rio Pinheiros é destaque em evento do SINICESP. Available online at: https://www.infraestruturameioambiente.sp.gov.br/2021/03/novo-riopinheiros-e-destaque-em-evento-do-sinicesp/ (accessed October 02, 2021).

São Paulo (State) (2020b). Tribunal de Contas do Estado-TCE. Despacho TCE $x$ EMAE. Available online at: https://www.tce.sp.gov.br/sites/default/files/ noticias/Despacho_TCESPxEMAE_0.pdf (accessed February 10, 2021).

Smith, K. R., Corvalán, C. F., and Kjellström, T. (1999). How much global ill health is attributable to environmental factors? Epidemiology 5, 573-84. doi: 10.1097/00001648-199909000-00027

United Nations (2021). Environmet Programme (UN). Available online at: https://www.unep.org/explore-topics/sustainable-development-goals/whydo-sustainable-development-goals-matter (accessed January, 2021).

Watson, V. (2019). The return of the city-region in the new urban agenda: is this relevant in the Global South? Regional Stud. 16:734. doi: $10.1080 / 00343404.2019 .1664734$
Yazar, M., Hestad, D., Mangalagiu, D., et al. (2020). From urban sustainability transformations to green gentrification: urban renewal in Gaziosmanpaşa, Istanbul. Climatic Change 160, 637-653. doi: 10.1007/s10584-019-02509-3

Conflict of Interest: The authors declare that the research was conducted in the absence of any commercial or financial relationships that could be construed as a potential conflict of interest.

Publisher's Note: All claims expressed in this article are solely those of the authors and do not necessarily represent those of their affiliated organizations, or those of the publisher, the editors and the reviewers. Any product that may be evaluated in this article, or claim that may be made by its manufacturer, is not guaranteed or endorsed by the publisher.

Copyright (c) 2021 Alves, Paz and Fracalanza. This is an open-access article distributed under the terms of the Creative Commons Attribution License (CC BY). The use, distribution or reproduction in other forums is permitted, provided the original author(s) and the copyright owner(s) are credited and that the original publication in this journal is cited, in accordance with accepted academic practice. No use, distribution or reproduction is permitted which does not comply with these terms. 